\title{
ROLE OF TRANSBRONCHIAL NEEDLE ASPIRA- TION IN DIAGNOSIS OF EXTRABRONCHIAL AND MEDIASTINAL LESIONS
}

\author{
$\mathscr{8 6 y}$ \\ Abo Bakr H. Al Asmar*, SMagd M. Galal*, Ahmed A. Abo Nagla*, \\ Abdelmonem A. Metwally*, Ibrahim H. Mohammad ${ }^{\star \star}$, Kamel \\ Abdelghafar Hasan*, Ahmed T. Khalil* and Esam Shawki ${ }^{\star}$
}

Trom

Chest diseases* and Pathology* Departments,

Al-Azhar Faculty of Medicine (cairo)

\begin{abstract}
The present study was designed to evaluate the diagnostic yield of TBNA in the diagnosis of extrabronchial and mediastinal lesions in order to avoid unnecessary mediastinoscopies or other surgical procedures.

This study included thirty patients. Twenty patients with clinical and radiological evidence of mediastinal lymph node enlargement, and ten patients with extrabronchial mass lesion causing an extraluminal compression who were admitted to Al Hussien university hospital and Bab El-Shariah university hospital, chest department in the period between May 2010 and May 2012. All patients wersubjected to the follow-
\end{abstract}

ing: history taking, clinical examination, plain chest $X$ - ray posteroanterior and lateral views, computerized tomography of the chest with contrast, routine laboratory investigations, fiberoptic bronchoscopy for inspection of the tracheobronchial tree and biopsy using TBNA, histopathological and cytological examination of the specimens. Some patients needed other investigations to confirm or reach the diagnosis such as mediastinoscopy, C.T guided biopsy and limited thoracotomy.

The diagnostic yeild TBNA in diagnosis of non-malignant lesions was $75 \%, 33 \%$ in sarcoidosis, $100 \%$ in TB and non-specific inflammation, and $77.7 \%$ in malignant lesions, $75 \%$

MANSOURA MEDICAL JOURNAL 


\section{ROLE OF TRANSBRONCHIAL NEEDLE ASPIRATION etc...}

in lymphoma and $80 \%$ in metastasis, and overall diagnostic yeild for mediastinal lesions was $76.47 \%$, sensitivity for small cell carcinoma was $100.0 \%$ and for non-small cell carcinoma was $62.5 \%, 80.0 \%$ for adenocarcinoma, 0 for squamous cell carcinoma and $100.0 \%$ for large cell carcinoma. The overall sensitivity for extrabronchial lesions was $70.0 \%$.

Conclusion: transbronchial needle aspiration provide a reasonable and accurate method in diagnosis of extrabronchial and mediastinal lesions.

\section{INTRODUCTION}

Lymph node enlargement can result from metastases, lymphomas, sarcoidosis, and tuberculosis (1) The diagnosis and staging of intrathoracic disease often requires a tissue diagnosis from lymph nodes adjacent to the tracheobronchial tree (2) The gold standard for histologic diagnosis is mediastinoscopy, mediastinotomy or an open lung biopsy however these procedures are invasive and complications can be serious (3).

Although mediastinoscopy is regarded as the accepted standard in the diagnosis of pathologic mediasti- nal lymph nodes, the reported sensitivity is $78 \%$ with a range of 40 to $92 \%$ (4). Transbronchial needle aspiration (TBNA) was first introduced by Wang et al. in late 1970s (5). Trans Bronchial Needle Aspiration (TBNA) is a valuable technique for sampling mediastinal lymph node and pulmonary parenchymal lesion (6). It is a safe, cheap and minimally invasive procedure, performed via a flexible bronchoscope with various sizes of retractable needles which are introduced through the suction port of the bronchoscope (3).

Conventional transbronchial needle aspiration (TBNA) avoided mediastinoscopy in $25 \%$ of the cases. TBNA can achieve a high diagnostic sensitivity for cancer in high probability patients and stage the majority appropriately, thereby avoiding unnecessary media-stinoscopies and reducing costs. It may also downstage a minority to have surgery (7). The major indications for TBNA include diagnosis of mediastinal or hilar adenopathy, extrinsic compression of the airway by a peribronchial process, submucosal disease, and peripheral nodule. Available studies have shown a high yield for diagnostic means, especially in malignant 
mediastinal and hilar lesions. The yield for TBNA varies widely in the literature (i.e., 20 to $89 \%$ ), and seems to be related to the size and location of the lesions, as well as to the operator's experience. However, the method is still underutilized (5).

\section{AIM OF THE WORK}

The aim of this study is to evaluate the diagnostic yield of TBNA in the diagnosis of extrabronchial and mediastinal lesions in order to avoid unnecessary mediastinoscopies or other surgical procedures.

\section{MATERIALS AND METHODS}

This study included thirty (30) patients. (20) patients with clinical and radiological evidence of mediastinal lymph node enlargement and (10) patients with extrabronchial mass lesion causing an extraluminal compression who were admitted to $\mathrm{Al}$ Hussien university hospital and Bab El-Shariah university hospital, chest department in the period between May 2010 and May 2012. Patient selection was based on:

Inclusion criteria: patients with enlarged subcarinal, paratracheal and hilar lymph nodes on CT. Mediastinal lymph nodes were regarded as enlarged if it was more than one $\mathrm{cm}$ in short-axis (as a CT finding) $(5,8)$ and patients with bronchoscopic picture of subcarinal widening or extraluminal compression with or without endobronchial lesions or masses were included in the present study.

Exclusion criteria included uncooperative patients, the presence of a coagulation disorder, lifethreatening arrhythmias or refractory hypoxemia, and inaccessible group of lymph node as prevascular lymph nodes (para-aortic or retrocaval) for fear of major complications.

The study aim and protocol was explained for each patient and an informed consent was obtained, then all patients were subjected to the following: history taking, clinical examination, plain chest $X$ - ray posteroanterior and lateral views, computerized tomographgy of the chest with contrast, routine laboratory investigations, fiberoptic bronchoscopy for inspection of the tracheobronchial tree and biopsy using TBNA, histopathological and cytological examination of the specimens. Some patients needed other investigations to confirm or reach the diagnosis such as mediastinoscopy, C.T guided biopsy. 


\section{ROLE OF TRANSBRONCHIAL NEEDLE ASPIRATION etc...}

Conventional fiberoptic bronchoscopy was done to all patients according to method described by Azam Khan, et al, $2008{ }^{(9)}$, and TBNA was done according to method described byKraft M 2007(3).

Criteria for pathological diagnosis,included adequate lymph node specimens were defined as those demonstrating lymphoid tissue on cytological and/or histological specimens (10), TBNA was accepted to be diagnostic for mycobacterial disease if the specimens revealed characteristic caseating granulomata, TBNA was also accepted as diagnostic of sarcoidosis if characteristic noncaseating granulomata were found on histologic examination, the diagnosis of malignancy was defined as the presence of malignant cells in the cytological specimens and/ or biopsy specimens. And nonspecific lymphadenitis was diagnosed by excluding other etiologies. After bronchoscopy, the vital signs (heart rate, blood pressure, and breathing) were monitored. Sometimes patients have an abnormal reaction to anesthesia, food or drink was not allowed for two hours after the procedure to avoid choking.

Vol. 42, No. 1 \& 2 Jan. \& April, 2013
Statistical analysis: The collected data were organized, tabulated and statistically analyzed using statistical package for social science (SPSS) version (16), running on IBM ${ }^{\circledR}$ compatible computer. Data were presented as frequency and percent distribution. Sensitivity was calculated from the quation (sensitivity = true positive (TP)/ true positive + false negative (FN)) (11).

\section{RESULTS}

This study include thirty patients, 19 males $(63.3 \%)$ and 11 females $(36.6 \%)$. The range of ages in males was from 33-73 years with a mean age of 55.05 years. In females the range of ages was from 45-63 years with a mean age of 52-72 years.

As regard diagnosis, mediastinal lesions were presented in 20 cases, 8 cases were non malignant (sarcoidosis in 3 cases (figure 1), tuberculosis in 1 case (figure 2) and nonspecific inflammation in 4 cases) and malignant in 9 cases (lymphoma in 4 cases (figures 3 and 4) and metastasis in 5 cases), and 3 cases were undiagnosed. On the other hand, submucosal and/or extrabronchial lesions were reported in 10 cases (2 were small cell carcinoma (figure 5) 
and 8 were non-small cell carcinoma). Non-small cell carcinoma was adenocarcinoma in 5 cases, squamous cell carcinoma in 2 cases and large cell carcinoma (figure 6) in 1 case (table 1). In the present study, it was noticed that 8 patients $(26.6 \%)$ had radiological evidence of enlarged all mediastinal lymph nodes and $26(86.6 \%)$ patients had radiological evidence of enlarged specific mediastinal lymph node. There were mass lesions in 15 patients and associated parenchymal lesions in 17 patients (table 2). In the present work, it was noticed that 13 patients (43.3\%) had subcarinal widening, 18 patients $(60 \%)$ had extraluminal compression and only 6 patients (20.0\%) had endobronchial lesions. Some patients had more than one finding (table 3 ). In the present study, the benign cases were 8 (40\%), 6 cases were diagnosed by TBNA and 2 cases was negative by TBNA and was diagnosed by mediastinoscopy. Also the same table shows that the malignant cases were $9(45 \%), 7$ cases were diagnosed by
TBNA and 2 cases were negative by TBNA but diagnosed by mediastinoscopy. The last three cases were not diagnosed neither by TBNA nor by other methods and still undiagnosed because patients refused to do any other interventions. In addition, 7 cases $(70 \%)$ out of 10 had been diagnosed to have bronchial carcinoma by TBNA where 3 cases $(30 \%)$ were negative by TBNA but diagnosed by endobronchial biopsy in 2 cases and CT guided biopsy in 1 case (table 4). In the present work, the diagnostic yeild of TBNA in diagnosis of non-malignant lesions was $75 \%, 33 \%$ in sarcoidosis, $100 \%$ in TB and non-specific inflammation, and $77 \%$ in malignant lesions, $75 \%$ in lymphoma and $80 \%$ in metastasis, and total diagnostic yeild for mediastinal lesions was $76.47 \%$, for small cell carcinoma was $100.0 \%$ and for non small cell carcinoma was $62.5 \%$, $80.0 \%$ for adenocarcinoma, 0 for squamous cell carcinoma and $100.0 \%$ for large cell carcinoma. The overall diagnostic yeild for extrabronchial lesions was $70.0 \%$ (table 5) 
212 ROLE OF TRANSBRONCHIAL NEEDLE ASPIRATION etc...

Table (1): Diagnosis of studied cases

\begin{tabular}{|c|c|c|c|}
\hline Parameters & & $N$ & $\%$ \\
\hline \multirow[t]{3}{*}{$\begin{array}{l}\text { Mediastrinal lesions } \\
(n=20)\end{array}$} & $\begin{array}{l}\text { Non malignant: } \\
\text { Sarcoidosis } \\
\text { Tuberculosis } \\
\text { Non specific inflammation }\end{array}$ & $\begin{array}{l}8 \\
3 \\
1 \\
4\end{array}$ & $\begin{array}{l}40.0 \% \\
15.0 \% \\
5.0 \% \\
20.0 \%\end{array}$ \\
\hline & $\begin{array}{l}\text { Malignant } \\
\text { Lymphoma } \\
\text { Metastasis }\end{array}$ & $\begin{array}{l}9 \\
4 \\
5\end{array}$ & $\begin{array}{l}45.0 \% \\
20.0 \% \\
25.0 \%\end{array}$ \\
\hline & Undiagnosed & 3 & $15.0 \%$ \\
\hline $\begin{array}{l}\text { Submucosal and/or } \\
\text { Extrabronchial lesions } \\
(n=10)\end{array}$ & $\begin{array}{l}\text { Small cell carcinoma } \\
\text { Non small cell carcinoma } \\
\text { Adenocarcinoma } \\
\text { Squamous cell carcinoma } \\
\text { Large cell carcinoma }\end{array}$ & $\begin{array}{l}2 \\
8 \\
5 \\
2 \\
1\end{array}$ & $\begin{array}{l}20.0 \% \\
80.0 \% \\
50.0 \% \\
20.0 \% \\
10.0 \%\end{array}$ \\
\hline
\end{tabular}

Table (2): CT findings in studied cases

\begin{tabular}{|c|c|c|c|c|c|c|c|}
\hline & \multirow{2}{*}{$\begin{array}{l}\text { All mediastinal LN } \\
\text { enlargement }\end{array}$} & \multicolumn{3}{|c|}{ Specific mediastinal LN enlargement } & \multirow[t]{2}{*}{ Mass lesion } & \multirow{2}{*}{$\begin{array}{l}\text { Associated } \\
\text { parenchymal } \\
\text { lesion }\end{array}$} \\
\hline & & & subcarinal & Hilar & Paratracheal & & \\
\hline \multirow{3}{*}{$\begin{array}{l}\text { Non } \\
\text { malignant }\end{array}$} & Sarcoidosis & $2 / 8(25.0 \%)$ & $3 / 8(37.5 \%)$ & $3 / 8(37.5 \%)$ & $3 / 8(37.5 \%)$ & $0(0.0 \%)$ & $3 / 8(37.5 \%)$ \\
\hline & TB & $0(0.0 \%)$ & $1 / 8(12.5 \%)$ & $1 / 8(12.5 \%)$ & $1 / 8(12.5 \%)$ & $1 / 8(12.5 \%)$ & $1 / 8(12.5 \%)$ \\
\hline & Non specific & $1 / 8(12.5 \%)$ & $1 / 8(12.5 \%)$ & $2 / 8(25.0 \%)$ & $4 / 8(50.0 \%)$ & $0(0.0 \%)$ & $2 / 8(25.0 \%)$ \\
\hline \multirow{3}{*}{ Malignant } & Lymphoma & $3 / 19(15.7 \%)$ & $3 / 19(15.7 \%)$ & $3 / 19(15.7 \%)$ & $3 / 19(15.7 \%)$ & $0(0.0 \%)$ & $2 / 19(10.5 \%)$ \\
\hline & Metastasis & $2 / 19(10.5 \%)$ & $4 / 199(21.05 \%)$ & $3 / 19(15.7 \%)$ & $5 / 19(26.3 \%)$ & $3 / 19(15.7 \%)$ & $4 / 19(21.05 \%)$ \\
\hline & $\begin{array}{l}\text { Bronchial } \\
\text { carcinoma }\end{array}$ & $\begin{array}{c}0 \\
(0.0 \%)\end{array}$ & $\begin{array}{c}0 \\
(0.0 \%)\end{array}$ & $\begin{array}{l}1 / 19 \\
(5.26 \%)\end{array}$ & $\begin{array}{c}3 / 19 \\
(15.7 \%)\end{array}$ & $\begin{array}{l}10 / 19 \\
(52.6 \%)\end{array}$ & $\begin{array}{c}3 / 19 \\
(15.7 \%)\end{array}$ \\
\hline \multicolumn{2}{|c|}{ Undiagnosed cases } & $0(0.0 \%)$ & $1 / 3(33.3 \%)$ & $3 / 3(100.0 \%)$ & $3 / 3(100.0 \%)$ & $1 / 3(33.3 \%)$ & $2 / 3(66.7 \%)$ \\
\hline
\end{tabular}

Table (3): Bronchoscopic findings in studied cases

\begin{tabular}{|c|c|c|c|c|c|c|c|}
\hline \multirow{2}{*}{ Type of lesion } & \multirow{2}{*}{ Parameters } & \multicolumn{2}{|c|}{ Widen main carina } & \multicolumn{2}{|c|}{ extraluminal compression } & \multicolumn{2}{|c|}{ Endobronchial lesions } \\
\hline & & $n$ & $\%$ & $\mathrm{n}$ & $\%$ & $n$ & $\%$ \\
\hline \multirow{3}{*}{$\begin{array}{l}\text { Non malignant } \\
\text { lesions }\end{array}$} & Sarcoidosis & $3 / 8$ & $37.5 \%$ & 0 & $0.0 \%$ & 0 & $0.0 \%$ \\
\hline & $\mathrm{TB}$ & $1 / 8$ & $12.5 \%$ & 0 & $0.0 \%$ & 0 & $0.0 \%$ \\
\hline & Non specific & $1 / 8$ & $12.5 \%$ & $3 / 8$ & $37.5 \%$ & 0 & $0.0 \%$ \\
\hline \multirow{3}{*}{$\begin{array}{l}\text { Malignant } \\
\text { Cases }\end{array}$} & Lymphoma & $4 / 19$ & $21.05 \%$ & $2 / 19$ & $10.5 \%$ & 0 & $0.0 \%$ \\
\hline & Metastasis & $3 / 19$ & $15.7 \%$ & $3 / 19$ & $15.7 \%$ & $3 / 19$ & $15.7 \%$ \\
\hline & Bronchial carcinoma & 0 & $0.0 \%$ & $7 / 19$ & $36.8 \%$ & $3 / 19$ & $15.7 \%$ \\
\hline \multicolumn{2}{|c|}{ Undiagnosed cases } & $1 / 3$ & $33.3 \%$ & $3 / 3$ & $100.0 \%$ & 0 & $0.0 \%$ \\
\hline
\end{tabular}

Vol. 42, No. 1 \& 2 Jan. \& April, 2013 
Table (4): Results of transbronchial needle aspiration (TBNA) in studied cases

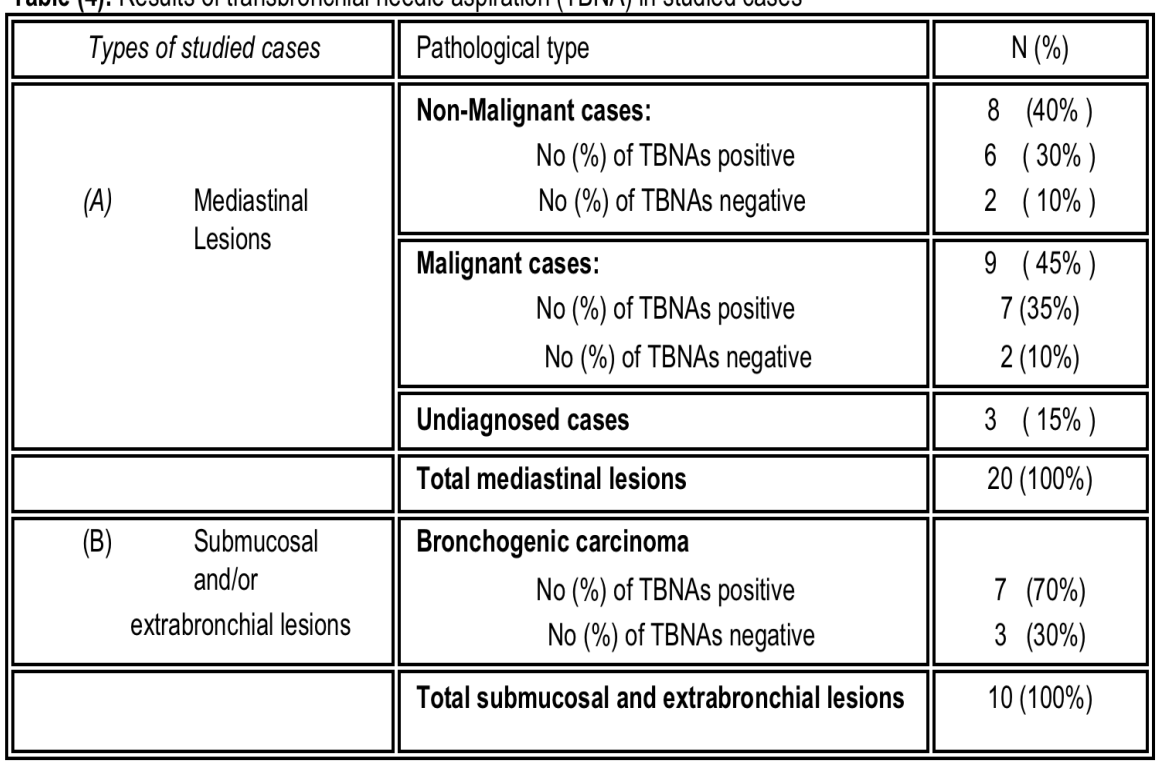

Table (5): Sensitivity of TBNA in the diagnosis of different Pathologies of studied cases with mediastinal lesions:

\begin{tabular}{||c|c|c||}
\hline Diagnosis & \multicolumn{2}{|c||}{ Diagnostic yield } \\
\hline \hline & $n$ & $\%$ \\
\hline \hline Non-malignant: & $6 / 8$ & $75 \%$ \\
- Sarcoidosis & $1 / 3$ & $33.3 \%$ \\
- Tuberculosis & $1 / 1$ & $100 \%$ \\
& $4 / 4$ & $100 \%$ \\
\hline \hline Malignant: & & $77.7 \%$ \\
- Lymphoma & $7 / 9$ & $75 \%$ \\
- Metastasis & $3 / 4$ & $80 \%$ \\
\hline \hline Total diagnostic yield & $4 / 5$ & $65 \%$ \\
\hline \hline Small cell carcinoma & $13 / 20$ & $100 \%$ \\
Non small cell carcinoma & $2 / 2$ & $62.5 \%$ \\
- Adenocarcinoma & $5 / 8$ & $80 \%$ \\
- Squamous cell carcinoma & $4 / 5$ & $0.0 \%$ \\
- Large cell carcinoma & $0 / 2$ & $100 \%$ \\
\hline \hline Total diagnostic vield & $1 / 1$ & $70 \%$ \\
\hline \hline
\end{tabular}


214 ROLE OF TRANSBRONCHIAL NEEDLE ASPIRATION etc...

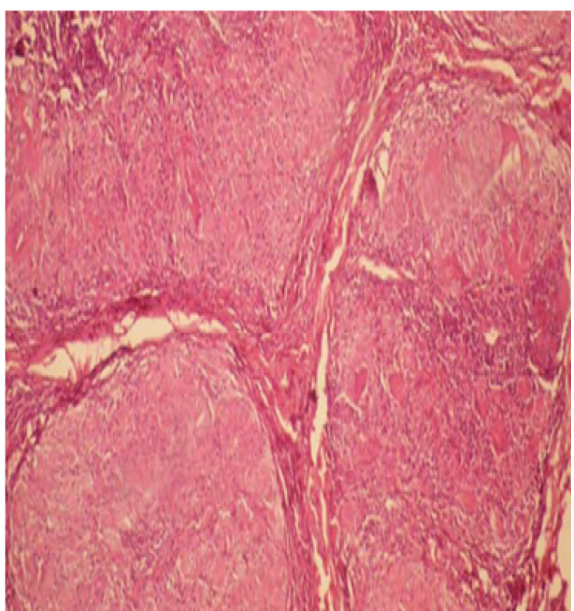

Figure (1): Sarcoid granuloma (low power).

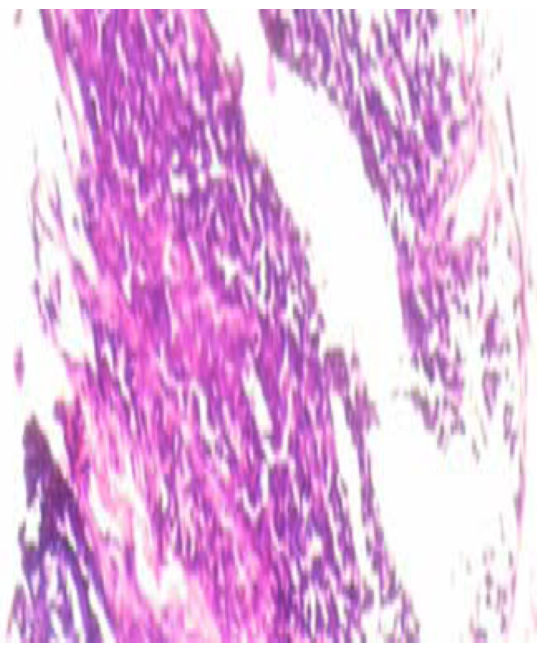

Figure (3) : NHL (low power).

Vol. 42, No. 1 \& 2 Jan. \& April, 2013

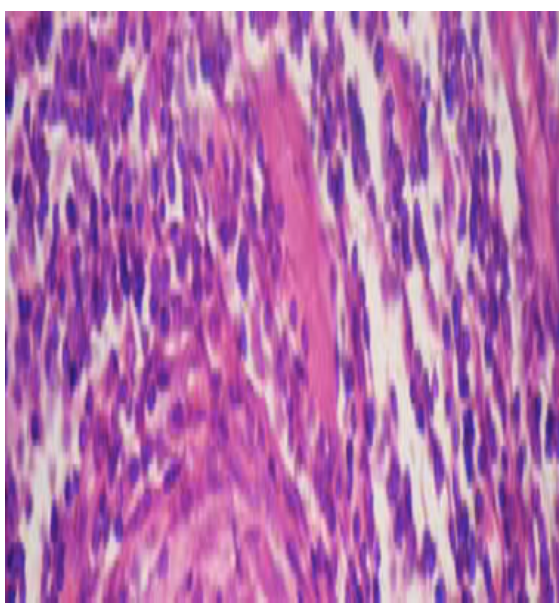

Figure (2): TB granuloma, high power. Multinucleated giant cells (Langhans cells), surrounded by epithelioid cells, T cell lymphocytes and few fibroblasts.

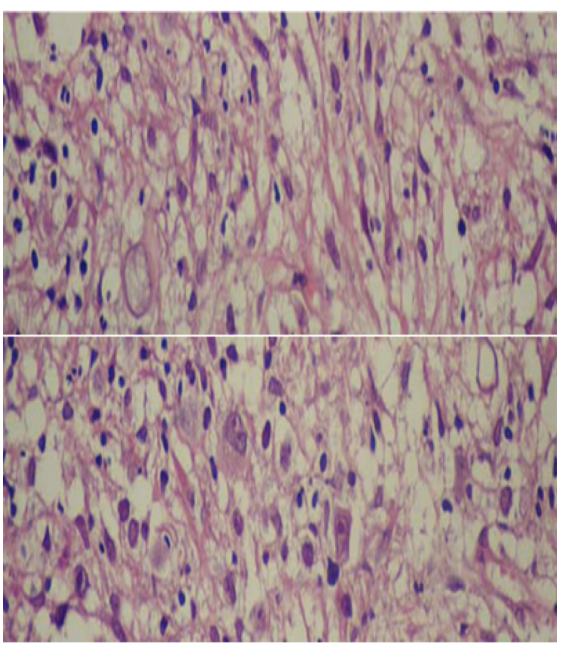

Figure (4) : Hodgkin lymphoma with Reed Sternberg cells and mature lymphocytes. 


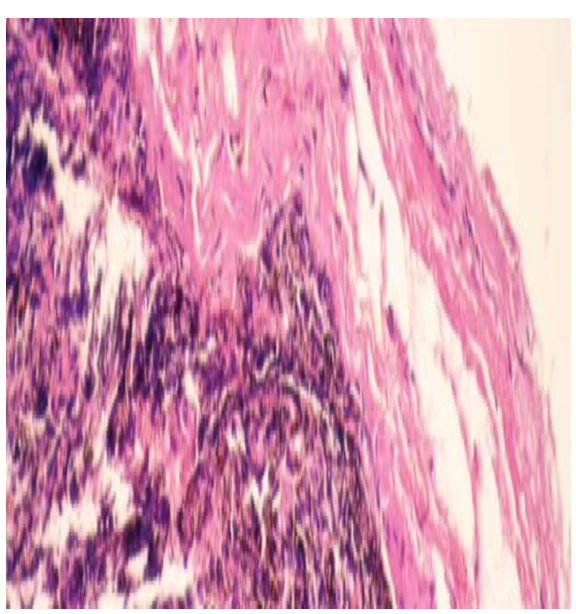

Figure (5): Small cell carcinoma, Low power.

\section{DISCUSSION}

TBNA dates back to 1949. An Argentinean surgeon named Eduardo Schieppati published his findings on subcarinal puncture in a review of the Argentine Medical Association (12). The technique of transbronchial needle aspiration has been available to bronchoscopists since 1958. Its modification for the fibreoptic instrument has considerably expanded its use (13).

The fifty six-year old TBNA has proved its efficacy, safety and costeffectiveness particularly in diagnosing and staging lung cancer as well as in diagnosing benign granulomatous disease: sarcoidosis and tuberculous lymphadenitis. Although high-

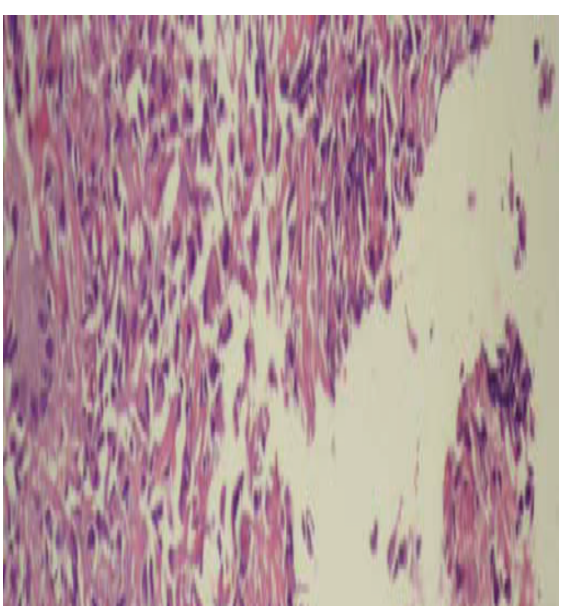

Figure (6): Undifferentiated large cell carcinoma, low power

ly specific, the sensitivity and accuracy of TBNA may vary depending on the study methods, patient population, and severity of disease and prevalence of mediastinal metastasis. Cost of the transbronchial aspiration needle might have an important impact on underused of TBNA particularly in developing countries and therefore cost of the needles should be either adapted to the income of the countries or should be manufactured locally (14).

This study aims to evaluate the role of TBNA in the diagnosis of mediastinal lymphadenopathy or any mass lesion causing extraluminal compression in a trial to reduce the use of more invasive techniques for MANSOURA MEDICAL JOURNAL 


\section{ROLE OF TRANSBRONCHIAL NEEDLE ASPIRATION etc...}

diagnosis such as mediastinoscopies or other surgical procedures. It was conducted in chest department, $\mathrm{Al}$ Hussein university hospital and Bab El-Shariah university hospital in the period between May 2010 and May 2012. Thirty hospitalized patients were included with clinical and radiological evidences of mediastinal lymph nodes enlargement or mass lesion causing extraluminal compression.

The yield for TBNA varies widely in the literature (i.e., 20 to $89 \%$ ), and seems to be related to the size and location of the lesions, as well as to the operator's experience. However, the method is still underutilized (5). In the study conducted by Boonsarngsuk et al 2009 (15), adequate lymph node samples were obtained in 33 out of 38 stations $(86.8 \%)$ and TBNA revealed definite diagnosis for 28 nodes $(73.7 \%)$ using a 21 -guage TBNA. In three patients, a definite diagnosis was established by other means- one by transbronchial needle biopsy (TBNB) using a 19-guage TBNB that revealed a tuberculous granuloma and two by VATS(Video Assisted Thoracoscopy) diagnosed as Castleman's disease and silicotic lymph node. These results are more or less matched with the current results.

The results obtained by the current study were in agreement with the results obtained by (16), who concluded that TBNA was diagnostic in 28 patients $(70 \%)$ and was not conclusive in 12 patients (30\%) with mediastinal lymphadenopathy. The results of the present study did not match with the results of the study conducted byAzam Khan et al 2008 (3), in which adequate lymph node samples were obtained in 23 out of 30 patients $(76.6 \%)$ and a definite diagnosis was made in 9 out of 30 patients $(30 \%)$. The higher results of the current study may be attributed to the different types and the sizes of the needles. The needle which was used in the present study was 19 gauge histology needle while the needle which was used in previous study was 21 gauge cytology needle and it was concluded from the previous studies (10), that the use of 19 gauge histology needle resulted in high diagnostic yield.

In the present study the diagnosis of mediastinal lesions by TBNA was reached in 13 patients out of twenty (65\%). The diagnostic yield was pos-

Vol. 42, No. 1 \& 2 Jan. \& April, 2013 
itive in $76.47 \%$ as the adequate specimens obtained by TBNA were 13 out of 17 cases who were finally diagnosed. These results were better than the results obtained byAliyali et al 2008 (5), who were able to make a diagnosis in 7 out of 16 patients $(43.7 \%)$ whose adequate lymph node samples were obtained by TBNA and had an overall TBNA yield $31.8 \%$. Also our results were better than the results obtained by Fernandes et al 2001 (17), who conducted a study upon 59 patients, in whom TBNA was performed to madiastinal $L N$. They found that adequate specimens were obtained in $45 \mathrm{pa}$ tients (76\% of cases) which were diagnostic in 35 patients (59\% of cases).

Also our results were better than the results obtained byHanan $\mathrm{HA}$ et al 2010 (18), who conducted a study upon 20 patients with mediastinal lymphadenopathy. They found that TBNA were diagnostic in 10 patients (50\% of cases. The study conducted by Khatab AM et al 1986 (19), included 13 patients with mediastinal lymphadenopathy and revealed a positive yield of TBNA in $46.15 \%$ of cases as it gives positive results in 6 patients out of 13 patients. These re- sults may be attributed, in part, to the size of the needle, number and types of patients. Harrow EM et al. (1989) (20), had performed TBNA to 633 patients with mediastinal lymph nodes enlargement. They obtained results which were different with the results of the current study as he had a positive yield in 127 patients (23\%) only.

The results of the current study were higher than the results of the study conducted by Croket JA et al 1999 (21), which included 96 patients and revealed a positive yield of TBNA in 42 patients (44\%). The results of the present study were also better than the results obtained by Harrow EM et al 1985 (13), who conducted a prospective multiinstitutional clinical study involving community hospitals and academic medical centers. TBNA was performed in 607 individual LN locations and 263 (43\%) were positive.

On the other hand the present results were lower than the results obtained by Prasad R et al 1993 (22), who examined 59 patients with mediastinal lymphadenopathy and reached a diagnostic yield of $91 \%$ (54 out of 59) which is higher than

MANSOURA MEDICAL JOURNAL 


\section{ROLE OF TRANSBRONCHIAL NEEDLE ASPIRATION etc...}

the results achieved in the current study.

The differences between this study and other studies may be due to the different selection criteria of patients, stage of disease, severity of granulomatous inflammation, degree of infiltration with malignant cells and experience of bronchoscopist and cytopatholgist.

Regarding to the diagnosed cases of mediastinal lesions, eight patients $(40 \%)$ had benign lesions and nine patients $(45 \%)$ had malignant lesions .but in diagnosed cases of extrabronchial lesions, two patients $(20 \%)$ had small cell carcinoma and eight patients $(80 \%)$ had non-small cell carcinoma. Among benign lesions, sarcoidosis has the lowest TBNA yield $(1 / 3,33.3 \%)$ of diagnosis. Tuberculin skin test gave no reaction in both cases. These results were greatly lower than the results obtained by Wang KP et al 1989 (23), who reported a $90 \%$ diagnostic TBNA yield with an 18-gauge needle in 20 patients with sarcoidosis (18 out of 20). The results obtained by Trisolini R et al 2003 ( 24), were better than the results obtained in the present study as he confirmed the di- agnostic value of flexible TBNA in stage ? sarcoidosis by showing an overall rate of $72 \%$ diagnostic yeild, using 19-gauge histologic needle. Also the results obtained by Trisolini $R$ et al 2008 (25), were better than the results of the present study. He examined 53 patients with sarcoidosis and non-necrotizing epithelioid granulomas were observed in 42 out of 53 patients (79\%).

In tuberculous patients, TBNA yield was positive in only one patient and was diagnosed by TBNA and was confirmed by limited thoracotomy. Tuberculin skin test was highly positive in this case. These results were in agreement with the results obtained by Cetinkaya E et al 2002 (10), who diagnosed all tuberculous cases with intrathoracic lymphadenopathies by using TBNA and TBNA was the only diagnostic procedure in $80 \%$ of the tuberculous patients.

The study conducted by Baran $\mathrm{R}$ et al $1996(26)$, reported that 5 of 11 patients with intrathoracic lymphadenopathies diagnosed by TBNA with a rigid bronchoscope. Harkin TJ et al. (1998) (27), reported that TBNA provided the diagnosis of mycobacterial disease in 20 of 23 HIV-infected pa-

Vol. 42, No. 1 \& 2 Jan. \& April, 2013 
tients $(87 \%)$, who had intrathoracic lymphadenopathies. The high TBNA yield in tuberculosis than in sarcoidosis in this study may be due to the size of lymph nodes as tuberculous case had larger lymph nodes about (3 cm short axis). In the study conducted by Azam Khan et al 2008 (3), the diagnosis of tuberculosis was made in 2 out of 3 patients using TBNA $(66.7 \%)$ This difference may be attributed, in part, to the number of patients and size of lymph nodes enlargement.

As regards to the four cases who were shown to have nonspecific lymph nodes enlargement, one of them had been diagnosed to have bronchiectasis, one had been diagnosed to have bronchial asthma, one had been diagnosed to have retrosternal goiter with anthracosis and the last one had been diagnosed to have COPD, hypertension and congestive heart failure. Non-specific lymph nodes enlargement was diagnosed by exclusion of other etiologies. It must be correlated with the clinical picture. It is reported that hypertrophy of mediastinal lymph nodes is not a usual sign of congestive heart failure. The enlarged lymph node localizations involved various mediastinal lymphatic chains with higher frequency in the subcarinal, paratracheal, and hilar nodes. The mechanisms underlying the pathogenesis of lymphadenopathy in congestive heart failure are unclear. It may be due to diffuse intrathoracic edema affecting the pulmonary parenchyma and neighbouring structures, including the mediastinum and associated lymph nodes (28), Reactive Follicular Hyperplasia (RFH) is a common abnormality seen on lymph node biopsy specimens, and in many instances the underlying cause is not known (idiopathic RFH) (29). In this study, the patient with bronchiectasis was diagnosed clinically and CT of the chest was used to confirm a clinical diagnosis of bronchiectasis. In the absence of other recognized causes of lymphadenopathy in this patient, this finding confirm "reactive" mediastinal lymph node enlargement in bronchiectasis (30).

The overall diagnostic yield of TBNA in all malignant cases of mediastinal lymphadenopathy was positive in 7 out of 9 patients (77.7\%). In lymphomas the diagnostic TBNA yield was positive in 3 out of 4 patients $(75 \%)$ and in metastasis was positive in 4 out of 5 patients (80\%). 
220 ROLE OF TRANSBRONCHIAL NEEDLE ASPIRATION etc...

These results were higher than the results obtained by Aliyali $M$ et al 2008 (5), who conducted a study upon 22 patients. In patients with malignancy (9 patients), TBNA provided diagnostic results in 5 patients (55.5\%). This difference may be due to the TBNA size which was 22 gauge cytology needles, as the results differed in different studies according to the size of the needle, in this study 19 gauge histology needle was used. In the study conducted by Azam Khan et al 2008 (3), Nineteen $(63.3 \%)$ of the whole 30 cases had lymphadenopathy amongest which adequate samples were obtained in 12 cases (63\%). Two cases $(10.5 \%)$ had carcinoma, $2(10.5 \%)$ had chronic granulomatous inflammation. Eight cases $(42.1 \%)$ were reported normal and in 7 cases $(36.8 \%)$ the samples obtained were inadequate. This difference may be related to the size of the lymph nodes and number of cases.

The overall diagnostic yield of TBNA in cases of submucosa and/or extrabronchial lesions was positive in 7 out of 10 patients $(70 \%)$. In small cell carcinoma (SCC) the diagnostic TBNA yield was positive in the 2 cases $(100 \%)$ and in non-small cell carcinoma (NSCC) was positive in 5 out of 8 cases $(62.5 \%)$. Of NSCC one patient $(100 \%)$ had larg cell carcinoma and 4 out of 5 patients $(80 \%)$ had adenocarcinoma. The 2 cases of squamous cell carcinoma reveal negative yield by TBNA. In the study conducted bySharafkhaneh $A$ et al 2003 (31), (60\%) of cases had adequate or diagnostic result by TBNA, $(69 \%)$ with malignancy and $(37 \%)$ with benign disease had a diagnostic TBNA . among primary pulmonary malignancies 26 out of 30 patients (87\%) with small cell carcinoma had a positive TBNA, while only 55 out of 86 patients $(64 \%)$ with non-small cell carcinoma had a positive aspirate. 14 out of 24 patients (58) had large cell carcinoma, 28 out of 40 patients (70\%) had adenocarcinoma and 13 out of 22 patients (59\%) had squamous cell carcinoma.

In our study and in the study conducted by Sharafkhaneh A et al 2003 (31), TBNA yield is higher for SCC, this was attributed to the biological aggressiveness of SCC, or to lower cellular adherence of these tumor cells

The current study showed that the overall diagnostic yeild of TBNA 
in diagnosis of all cases with mediastinal lymphadenopathy was $65.47 \%$ $(13 / 20)$. It was noticed that the overall sensitivity of TBNA in nonmalignant group was $75 \%(6 / 8)$. The diagnostic yeild in sarcoidosis was $33.3 \%(1 / 3)$, in tuberculosis was $100 \%(1 / 1)$, and in non-specific inflammation $100 \%(4 / 4)$. In malignant group the overall diagnostic yeild of TBNA was $77.7 \%$ (7/9). The diagnostic yeild in lymphoma was $75 \%$ (3/4) and in metastasis were $80 \%$. In addition, this study showed that the overall diagnostic yeild of TBNA in diagnosis of all cases with submucosa and/or extrabronchial lesions was $70 \%(7 / 10)$. It was noticed that the overall diagnostic yeild of TBNA in SCC was $100 \%(2 / 2)$, the diagnostic yeild of TBNA in NSCC was $62.5 \%$ $(5 / 8)$. The diagnostic yeild in adenocarcinoma was $80 \%(4 / 5)$ and in large cell carcinoma $100 \%$ (1/1). These results were more or less matching with the results obtained byHsu LH et al 2004 (32). His study included 90 patients, 66 patients with hilar-mediastinal lymphoadenopathies and 24 patients for submucosal and/or peribronchial lesions. TBNAs were done to all those patient using 21-gauge cytology needles or 19gauge histology needles connected to a flexible bronchovideoscope. The results showed that the diagnostic yield was $68.2 \%$ (45 of 66 patients) for hilar-mediastinal lesions and $70.8 \%$ (17 of 24 patients) for submucosal and peribronchial lesions. The diagnostic yeild was $75 \%$ (45 of 60 patients) for hilar-mediastinal lesions, and $80.9 \%$ (17 of 21 patients) for submucosal and peribronchial lesions. The overall accuracy of the procedure for returning a correct diagnosis was $75.9 \%$ (66 of 87 patients). Also the current results were better than the results obtained by Khoo KL (33), as he carried out a study of forty-five consecutive patients who underwent TBNA as part of diagnostic bronchoscopy during a 2-year study period. TBNA gave a yield of $65 \%$ for evaluation of mediastinal disease, both benign and malignant. The overall diagnostic utility for all indications was $71 \%$ and there were no complications.

TBNA using 19-gauge histologic needles through a flexible bronchoscope is a valuable tool in the differential diagnosis of intrathoracic adenopathies. This method seems to be rapid, safe and effective in the diagnosis not only of malignant disease, but also of benign intrathoracic ade-

MANSOURA MEDICAL JOURNAL 
222 ROLE OF TRANSBRONCHIAL NEEDLE ASPIRATION etc...

nopathies, particularly tuberculosis and sarcoidosis $(10)$. Histologic material can reveal additional diagnostic information compared with sole cytologic examination in $14 \%$ of representative TBNA samples in patients with mediastinal lymph node enlargement ${ }^{(34)}$. Conventional transbronchial needle aspiration (TBNA) is a cheap, minimally invasive tool for lung cancer staging and diagnosis. TBNA avoided mediastinoscopy in $25 \%$ of the cases. TBNA can achieve a high diagnostic sensitivity for cancer in high probability patients and stage the majority appropriately, thereby avoiding unnecessary mediastinoscopies and reducing costs. It may also down-stage a minority to have surgery $(7)$.

In short, transbronchial needle aspiration provide a reasonable and accurate method in diagnosis of extrabronchial and mediastinal lesions.

\section{REFERENCES}

1- Kunihiro Y, Yasuyuki K, Ken K, Hiroshi $N$, Junichi $M$ and Yasuo N (2003) : Evaluation of the Mediastinal Shadow on Chest Radiographs: Anatomy, Normal
Variants, and Pathology. The Radiologist, 10(5), 209-220.

2- Goldberg SN, Raptopoulos V, Boiselle PM, Edinburgh KJ and Ernst A (2000) : Mediastinal Lymphadenopathy: Diagnostic Yield of Transbronchial Mediastinal Lymph Node Biopsy with CT Fluoroscopic Guidance-Initial Experience. Radiology, 216:764-767.

3- Azam Khan MK, Ansari JK, Saeed W, Baig IM, Humayun $Z$ and Khalil KF (2008) : Diagnostic yield of transbronchial needle aspiration analysis of 30 cases. J Ayub Med Coll Abbottabad, 20(3):132-4.

4- Ernst A, Anantham D, Krasnik $M$ and Herth FJF (2008) : Diagnosis of Mediastinal Adenopathy-Real-Time Endobronchial Ultrasound Guided Needle Aspiration vs Mediastinoscopy. J Thorac Oncol, 3: 577-582.

5- Aliyali M and Shafigh E (2008) : 
Diagnostic Yield of Transbronchial Needle Aspiration in Intrathoracic Lymphadenopathy. Tanaffos, 7(2): 23-27.

6- Baram D. (2004) : Comparison of the diagnostic accuracy of transbronchial needle aspiration for bronchogenic carcinoma and other malignancies. J Bronchol, 11:87-91.

7- Medford AR, Agrawal S, Free $C M$ and Bennett JA (2010a) : A Prospective Study of Conventional Transbronchial Needle Aspiration: Performance and Cost Utility. Respiration, 79: 482-489.

8- Wang MZ, Wan XB, Cai $B Q$ and Li LY (2009) : The results of transbronchial needle aspiration in 164 cases with enlarged mediastinal and/or hilar lymph nodes. Zhonghua Nei Ke Za Zhi, 48(2):133-5 (English abstract).

9- Kraft M (2007) : Approach to the patient with respiratory disease In: Goldman L, Ausiello D, eds. Cecil Medicine. 23rd ed. Philadelphia, $\mathrm{Pa}$ : Saunders Elsevier, chap 83, pp 512-516.

10- Cetinkaya E, Yildiz P, Kadakal F, Tekin A, Soysal F, Elibol $S$ and Yilmaz $V$. (2002) : Transbronchial Needle Aspiration in the Diagnosis of Intrathoracic Lymphadenopathy. Respiration, 69:335-338.

11- Saltelli A, Ratto M, Tarantola $S$ and Campolongo $F$ (2012) : Update 1 of: Sensitivity analysis for chemical models. Chem Rev, 112(5):PR1-21.

12- Medford AR, Bennett JA, Free $C M$ and Agrawal $S$ (2010b) : Endobronchial ultrasound guided transbronchial needle aspiration. Postgrad Med J, 86 (1012):106-15.

13- Harrow EM, Oldenburg FA and Smith AM (1985) : Transbronchial needle aspiration MANSOURA MEDICAL JOURNAL 
224 ROLE OF TRANSBRONCHIAL NEEDLE ASPIRATION etc...

in clinical practice Thorax, 40:756-759.

14- Bilaceroglu $S$ and Chhajed $P$. (2005) : Transbronchial Needle Aspiration: A Diagnostic Tool in Routine Bronchoscopy. JAPI, 53: 797-802.

15- Boonsarngsuk, V. and Pongtippan, A. (2009) : SelfLearning Experience in Transbronchial Needle Aspiration in Diagnosis of Intrathoracic Lymphadenopathy J. Med. Assoc. Thai, 92 (2): $175-81$

16- Soliman MA, Khattab HM, Aref HM and Elkorashy RI (2006) : Role of the Transbronchial needle aspiration in the diagnosis of mediastinal lesions. Egyptian Journal of Chest, 5: 209-215.

17- Fernandes viller JA, Iglesias Rio $F$ and Pineiro Amigo L (2001) : Clinical usefulness and cost- effectiveness of transbronchial needle aspiration in the diagnosis of mediastinal adenopathy. Rev. Clin. Res, 201 (4): 169-173.

18- Hanan HA, Galal EI-Din MM, Abd El Sabbour $M$ and Moussa L (2010) : Evaluation of transbronchial needle aspiration in diagnosis of mediastinal lesions. MD Thesis, Faculty of medicine for girls, Al Azhar University.

19- Khattab AM, Youssef HH, ElHelaly ES, Safwat $T$ and El-Tawil A (1986) : Transbronchial needle aspiration in the diagnosis and staging of intrathoracic malignancies (M.D Thesis), AinShams University.

20-Harrow EM, Oldenburg FA, Lingenfelter MS and Smith, A.M. (1989) : Transbronchial needle aspiration in clinical practice, A fiveyear experience. Chest, 96 (6): 1268-1272.

21- Croket JA, Wong EY, Lien DC, Nguyen KG, Chaput MR and Mcnamee C (1999) : Cost effectiveness of trans- 
bronchial Needle Aspira-

tion. Can Respir. J, 6

(4):332-5.

22- Prasad R, Garg SK, Mukerji PK and Agarwal PK (1993) : Role of fine needle aspiration cytology in the diagnosis of Lymphadenopathy. Indian J. Chest Dis. Allied Sci, 35(1): 27-29.

23- Wang KP, Fuenning C, Johns CJ and Terry PB (1989) : Flexible transbronchial needle aspiration for the diagnosis of sarcoidosis. Ann Otol Rhinol Laryngol, 98 (4 Pt 1): 298- 300.

24- Trisolini R, Agli LL, Tinelli C, Baruzzi $G$ and Patelli $M$ (2003) : The value of flexible transbronchial needle aspiration in the diagnosis of stage I sarcoidosis. Chest, 124 (6): 2126- 30.

25- Trisolini R, Tinelli C, Alifano $M$, Boaron $M$ and Patelli, M. (2008) : Transbronchial needle aspiration in sarcoidosis: Yield and predictors of a positive aspirate. $J$
Thorac Cardiovasc Surg, 135:837-842

26- Baran $\mathbf{R}$, Tor $\mathbf{M}$, Tahaoglu $\mathrm{K}$, Ozvaran K, Kir A, Kizkin $O$ and Turker H (1996) : Intrathoracic tuberculous lymphadenopathy: Clinical and bronchoscopic features in 17 adults without parenchymal lesions. Thorax, 51:87-89.

27- Harkin TJ, Ciotoli C, Naidich DP, Jagirdar $\mathrm{J}$ and Rom WN (1998) : Transbronchial needle aspiration (TBNA) in patients infected with HIV. Am J Respir. Crit. Care Med, 157 : 1913-1918.

28- Ngom A, Dumont $P$, Diot $P$ and Lemarie E (2001) : Benign mediastinal lymphadenopathy in congestive heart failure. Chest, 119 (2): 653656.

29- Good DJ and Gascoyne RD (2009) : Atypical lymphoid hyperplasia mimicking lymphoma. Hematol Oncol Clin N Am, 23(4):729-745.

MANSOURA MEDICAL JOURNAL 
226 ROLE OF TRANSBRONCHIAL NEEDLE ASPIRATION etc...

30- Thomas RD and Blaquuiere RM (1993) : Reactive mediastinal lymphadenopathy in bronchiectasis assessed by CT. Acta. Radiol, 34 (5): 489-91.

31- Sharafkhaneh $A$, Baaklini $W$, Gorin $A B$ and Green $L$ (2003) : Yield of transbronchial needle aspiration in diagnosis of mediasyinal lesions. Chest; 124: 21312135.

32- Hsu LH, Liu CC and Ko JS (2004) : Education and experience improve the performance of transbronchial needle aspiration: a learn- ing curve at a cancer center. Chest, 125(2):532-40.

33- Khoo, KL, Chua GS, Mukhopadhyay $A$ and Lim TK (2003) : Transbronchial needle aspiration: initial experience in routine diagnostic bronchoscopy. Respir Med, 97(11):1200-4.

34- Hermens HW, Limonard JM, de Kievit $I$ and Janssen $P$ (2010) : Diagnostic Value of Histology Compared with Cytology in Transbronchial Aspiration Samples Obtained by Histology Needle. Journal of Bronchology, 17 (1): 19-21. 


\title{
الملخص العربى
}

دور إبرة الشفط عبر منظار الشعب الهوائية فى تشخيص

\section{الاصابات خارج الشعب الهوائية والحيزوم الصلدىى}

\author{
أبوبكر هلال الأسمر مجد محمد جلال * أحمد على أبو نجله*،

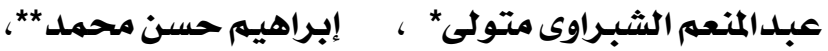

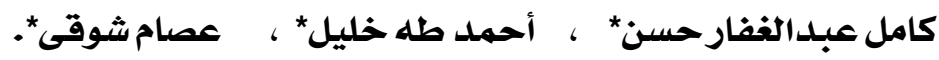 \\ قسمى الأمراض الصدرية"، والباثولوجى ** كلية طب الأزهر
}

صـمـمت الدراسـة الحالية بهدف تقييم دور إبرة الشفط عبر الشعب الهوائية (TBNA) فى تشخيص إصـابات الغدد الليمفـاوية و الاورام داخل الحيزوم وكذلك الاصـابات خارج الشعب الهوائية. وذلك للحد من استخدام العينات الجراحية لأخذ عينات من الحيزوم.

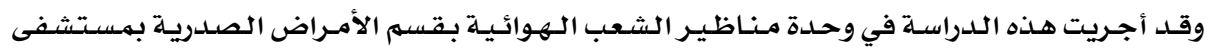
الحسين الجامعي ومستشفى باب الثعرية الجامعي وكليـة الطب بجامعة الأزهر في الفترة من مايو 2010

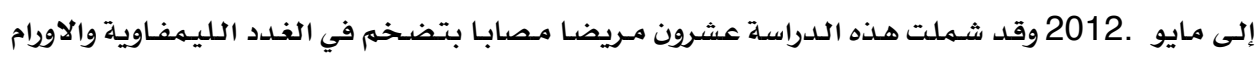
داخل الحيزوم، وعشـرة مرضى مصـابين بأورام خـارج الشعب الهوائية مسببـة ضغطا من الخارج على تجويف تلك الشعب وتم التعـرف علـيهم عن طريق الفحص الإكلينيكي وباستخـــام أشعـة الصـدر العـادية والأشعـة المقطعية.وقد تم عمل منظار شعب هوائية لجميع الحالات و أخذ عينة بذل مـن خلال الشعب الهوائية من الغلدد الليمفاوية المتضخمـة ومن الأورام الضاغطة على تجويف الشعب الهوائية باستخدام إبرة الشفط عبر الشعب الهوائيـة كمـا تم فحص هـذه العينات خلـويـا و نسيـجيا تحت الميكروسكوب للـوصول للتشخيص النهائي. وقد اسفرت نتائج الدراسـة على أن النـاتج التشخيصي للابرة في تشخيص الأمـراض غيـر السـرطانية

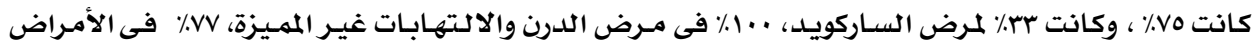

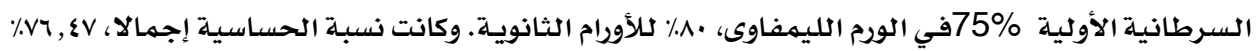

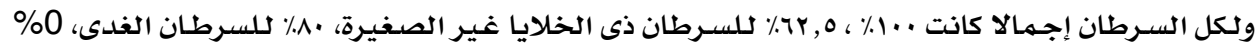
لسـرطـان خلايا النسـيج الطلائى، .. 1٪ لسـرطـان الخلايا الكبـيرة. وكانت النسبـة العـامـة للأمراض داخل

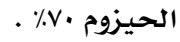
MANSOURA MEDICAL JOURNAL 